Restoration of Buildings and Monuments

\title{
Revitalisation of the ruins of the Abbey-Tower at Sint-Truiden
}

D. Van Gemert, KU Leuven and Triconsult n.v.

K. Brosens, Triconsult n.v. and UHasselt

H. van Meer, Team van Meer! architecten \& Co cvba, Hasselt

\begin{abstract}
The restoration of the ruins of the Abbey-Tower in the city centre of Sint-Truiden in Belgium is presented as an example of the tedious and comprehensive task involved in all restoration or rehabilitation projects, where the extra cost of the restoration must be justified by the added value connected with the conservation of authenticity and with the contribution to sustainable development. The development and evolution of the project took 28 years, between the damages caused by the fire in 1975 and the start of the restoration in 2003. Since 2004, the restored ruin started a new life as a beacon of the city of Sint-Truiden, highly appreciated by tourists as well as by the inhabitants.
\end{abstract}

Keywords: restoration, ruin, opening up, consolidation, fire damage

\section{Introduction}

The idea of restoration of monumental constructions and buildings goes back to the 19th Century. Conservation as an essential aspect in monument care is a concept from the 20th Century. The vision and attitude towards restoration and conservation depend on place and time. This vision is determined in a number of Charters, of which the most well known is the Venice Charter of 1964. These charters are important directives for actual restoration and conservation practice. Restoration in many cases means an additional cost compared to new construction with equal functionality. This extra cost must be justified by the conservation of authenticity and by the potential contribution to sustainable development. The restored building must be integrated in the built and in the social environment: it must contribute to sustainable development in material sense as well as in social sense.

The restoration of the tower of the Saint Trudo Abbey at Sint-Truiden is an example of such a tedious, balancing and mostly time consuming process $[1,2]$. The tower is the only remaining part of the medieval church (1055-1082) constructed by abbot Adelardus II. That church had a length of $100 \mathrm{~m}$ and a width of $26 \mathrm{~m}$. After the French occupation from 1794, the church was broken down in 1798, except the tower. In 1845 a smaller seminar school church was constructed adjacent to the old tower. On $9^{\text {th }}$ December 1975 the seminar church completely burned down together with part of the abbey buildings. The fire also transformed the tower into a ruin. After long and tedious discussions of the Flemish Heritage and Monuments Department with the owners and with the population of the city of Sint-Truiden, it was finally decided to revitalise the tower ruin by making it accessible to the public, as part of the comprehensive rehabilitation project 'Kerkveld'(Church Field) in the city centre 
comprising not only the tower, but also the remains of the former church, its crypt, a small theatre, all closely connected to the Great Market place of Sint-Truiden. The architect in charge was Herman van Meer. The project was executed in 2003-2004.

\section{History of Abbey-Tower at Sint-Truiden}

Before 1975 the central market place of Sint-Truiden was dominated by three towers: the tower of the Abbey, the tower of the City Hall, and the tower of the church of Our Lady Mary, Figure 1.

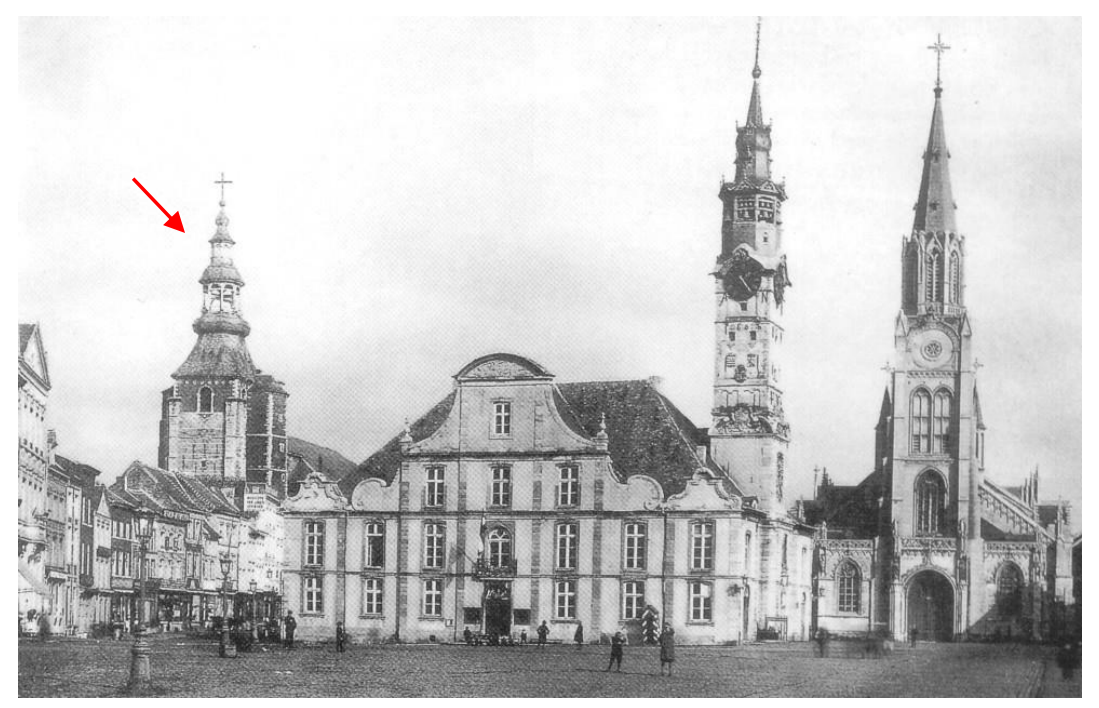

Figure 1: Photograph of market place of Sint-Truiden, view to east: left Abbey Tower (highlighted with an arrow); middle City Hall Tower; right Our Ladies Church Tower (1926) (Fototheek St.-Truiden)

After the huge fire of the church on 9th December 1975, the tower shaft and the crypt under the choir became the only remaining parts of the church as it was constructed by abbot Adelardus II (1055-1082), at that time one of the largest Ottonic churches.

The first and second church, built at the same place, had no tower. Only in 1045 the construction of the first tower started. In 1056 the central tower reached a height of $31.5 \mathrm{~m}$, and was flanked by two staircase towers of $34.5 \mathrm{~m}$ high, Figure 2 .

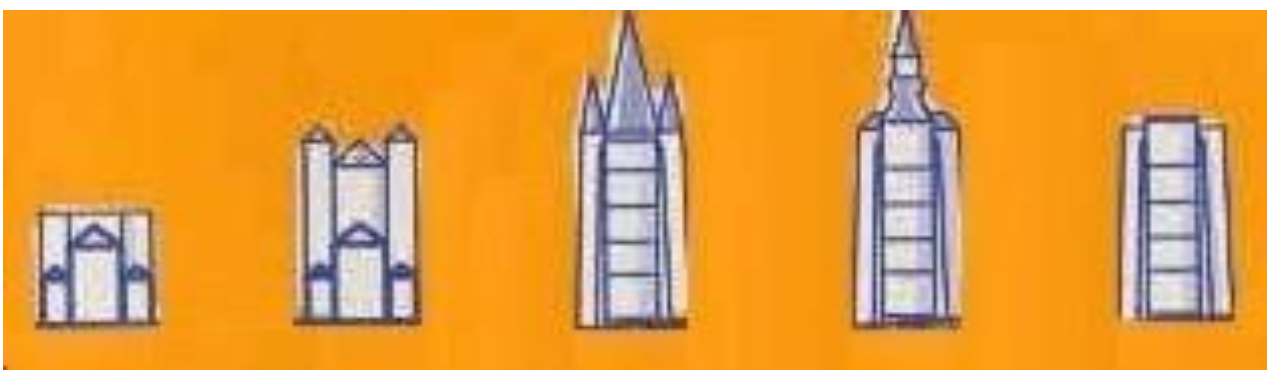

Figure 2: Successive tower constructions and adaptations [1] 
That tower was covered with a Romanesque roof, characterised by a low roof-slope. The west wall of the tower collapsed in 1263, and was reconstructed with orthogonal buttresses, as can be seen in Figure 3. In the $14^{\text {th }}$ Century a fifth storey was added as well as a Gothic spire. In the $16^{\text {th }}$ Century there were three spires. In 1779 abbot Jozef Van Herck removed the spires, raised the fifth storey to a height of $45 \mathrm{~m}$, and finished the tower with a classicistic spire with gallery. During the French occupation the abbey-buildings were sold in 1798 and parts of them broken down, including the church except the tower. In 1802 the abbey buildings were sold a second time, and in 1803 they were donated to two monks. In 1824 the site was donated to the church fabric of Our Lady, situated just aside. The abbey became a catholic school (seminarschool) in 1843 and a new seminar-church was built adjacent to the tower in 1845. In October 1952 the $13 \mathrm{~m}$ tall spire felt down, through the roof of the church. In 1954 the spire was repaired. Finally on $9^{\text {th }}$ December 1975 the fire destroyed the spire of the tower, the church and part of the school buildings. At the end of 1976, according to the spirit of the age and notwithstanding multiple objections of historians, the school administration was allowed to construct new school buildings at the location of the church nave, thus making impossible any reconstruction of the church nave. The tower remained as a ruin, Figure 3. The height of the tower shaft is $34.5 \mathrm{~m}$. The wall thickness changes from $1.9 \mathrm{~m}$ at the ground level, to $1.2 \mathrm{~m}$ at the top.

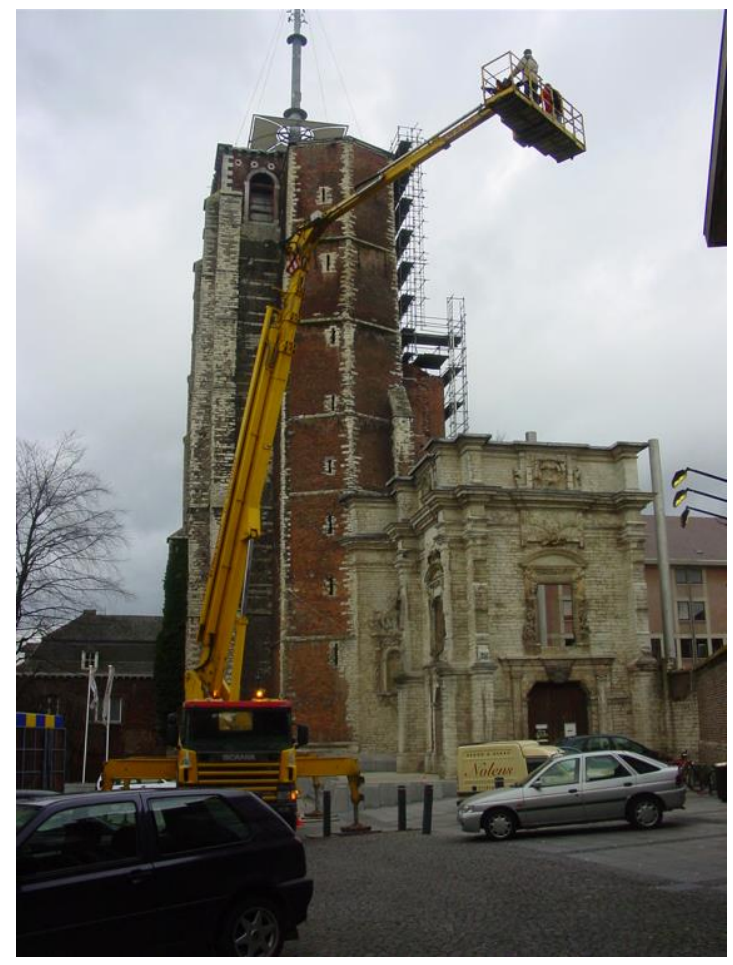

Figure 3: Ruin of tower after fire of 1975. Baroque gate at the right of the tower.

At the millennium turn 2000 , a temporary metal spire with a height of $18 \mathrm{~m}$ was installed, with webcams that could be consulted via internet, Fig. 4. It was inaugurated at midnight $00 \mathrm{~h} 00$ on 01.01 .2000 


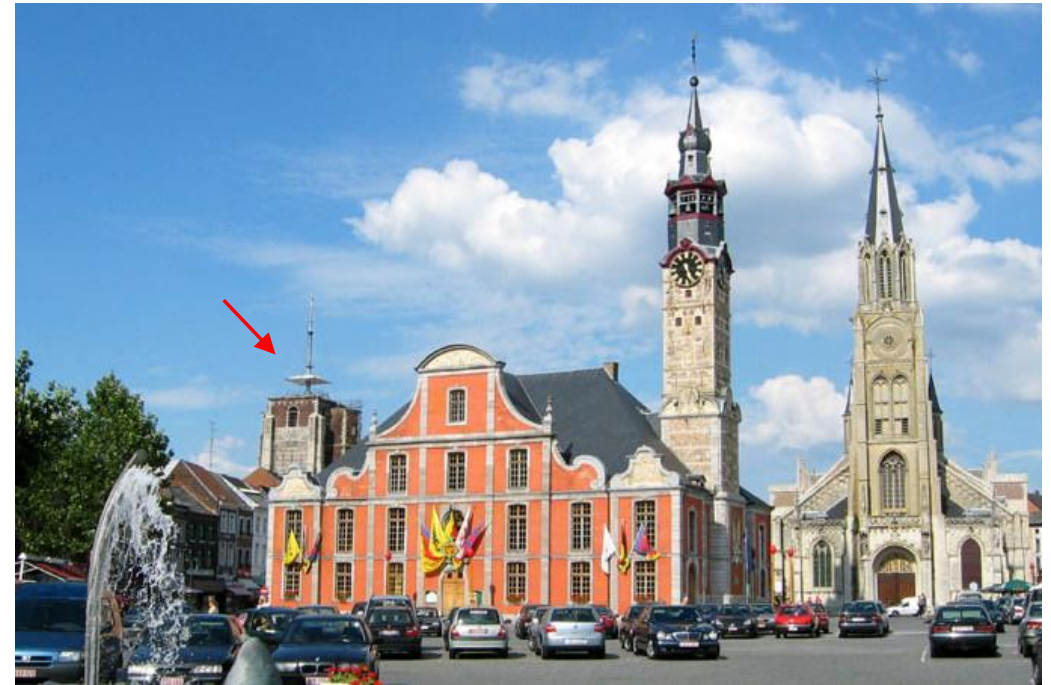

Figure 4 Three towers at market place of Sint-Truiden. Abbey Tower with a metal spire on top is highlighted with an arrow (2001)

However, that skinny metal construction could not please the inhabitants of SintTruiden. So discussion on the restoration started again, which led to the project of integration and opening up of the tower, as it was executed in 2004.

\section{Integrated site revitalisation project 'Kerkveld' [3]}

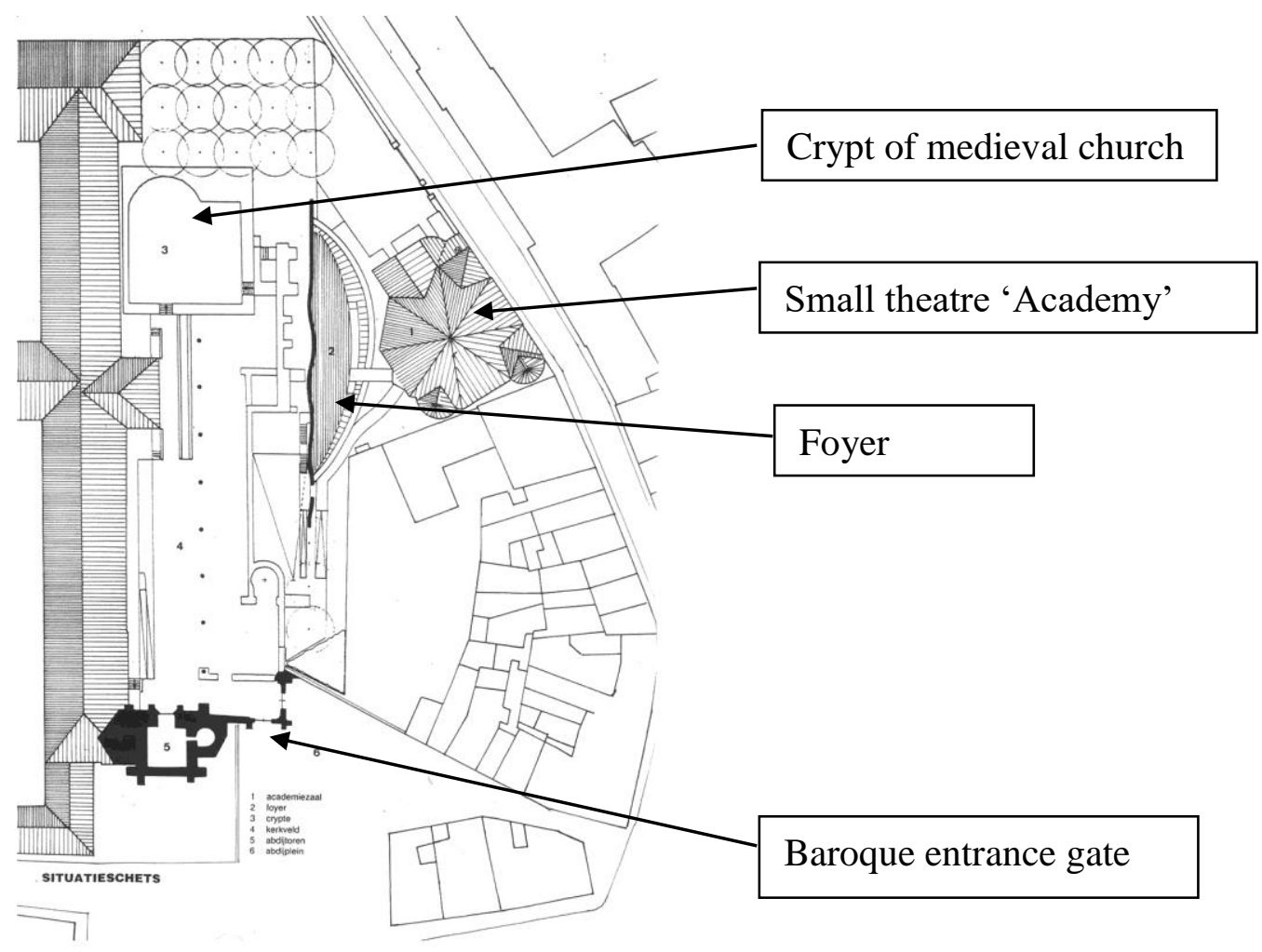

Figure 5: Site revitalisation plan of Abbey-Tower and Kerkveld (Church field) 


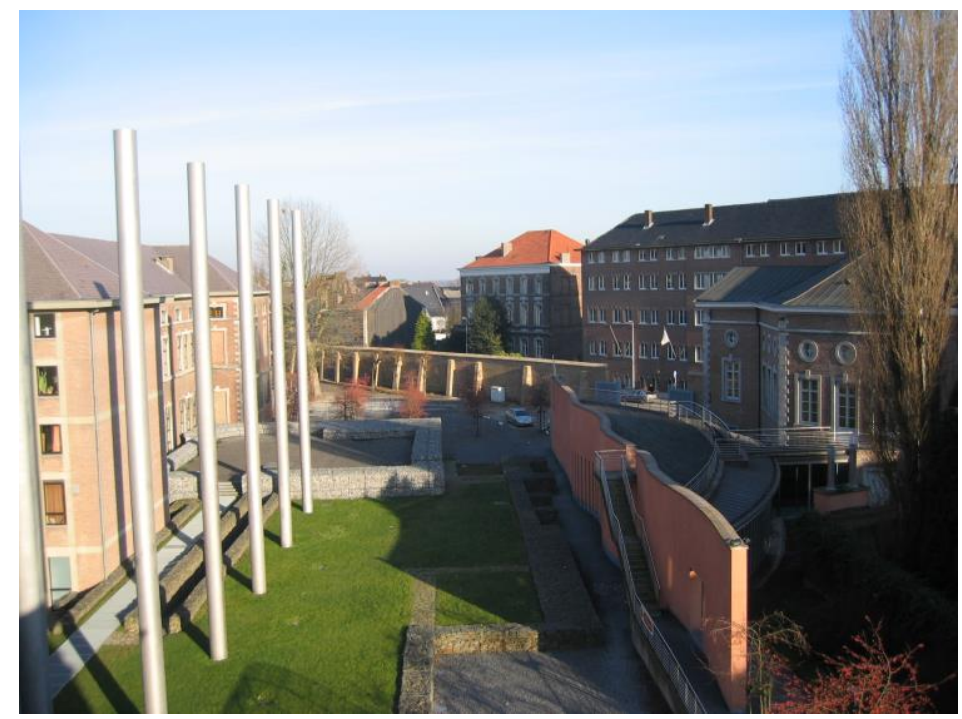

Figure 6: Church field east of tower, with school building (left, 1976), Foyer (right, 1997) and Academy (1839). Stainless steel columns simulate former pillars of the medieval church.

The tower shaft as a beacon of the town is situated at the border between the urban area of the market place and the more introvert area of the abbey site, which is the birthplace of the town. The tower shaft has a multiple relation with the church field and with the town. The opening up concept of the tower focuses on this duality of the beacon aspect. The opening up concept does not envisage anymore the tower as part of the religious church building, because the church function as well as the church building disappeared. If a choice for the church tower aspect had been made, the shaft as a beacon would loose the continuing link with the historical process and story. The followed concept deepens the meaning of the place within the vanished abbey, absorbed by the urban tissue that developed around the abbey.

The opening up concept aims to re-discover the beacon function of the tower shaft throughout history, as well as the in-between function of the shaft in space and in history. The meaning evolves from 'tower of the abbey church' to 'historical beacon and relict' around which the town clusters and orientates itself.

The tower is conceived to be a key element in the relation between town and abbey site. In the centre of the town the market place is connected via the Baroque entrance gate (1655, Fig. 5) with the church field. In this church field eight stainless steel columns (Figure 6) simulate the nave of the Ottonic church, the walls of this church being indicated with stone baskets (gabions). The crypt is situated under the vanished choir. More recent are the academy-hall (1845) and the recently built foyer (1995) to provide the necessary modern comfort to this academy theatre.

\section{Opening up of Abbey-Tower}

The visitor enters the church field through the Baroque gate (Figure 5). He enters the tower through the old passage from church to tower, Figure 7. 


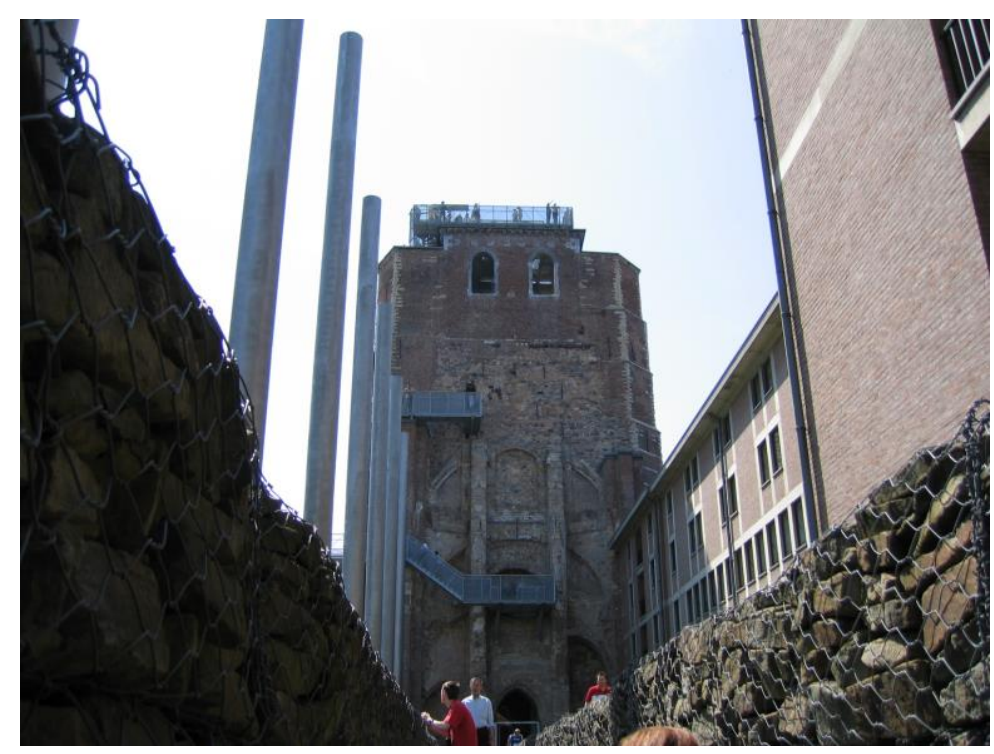

Figure 7: Entrance of tower through passage door at ground level. View from entrance to crypt. Left: stainless steel columns. Right: new school building (1976)

A steel staircase at the inside of the shaft leads the visitor to the "Emperor's loge", where the Austrian emperor used to sit when attending the holy Mass [4].

Now the visitor stays in the church space. From below one could get a global picture of the east façade of the tower. Now the visitor can nearly touch the wall, and read the traces of construction history. A stairway leads from the emperor's loge to an opening up platform at the level of the Baroque gate, Figure 8.

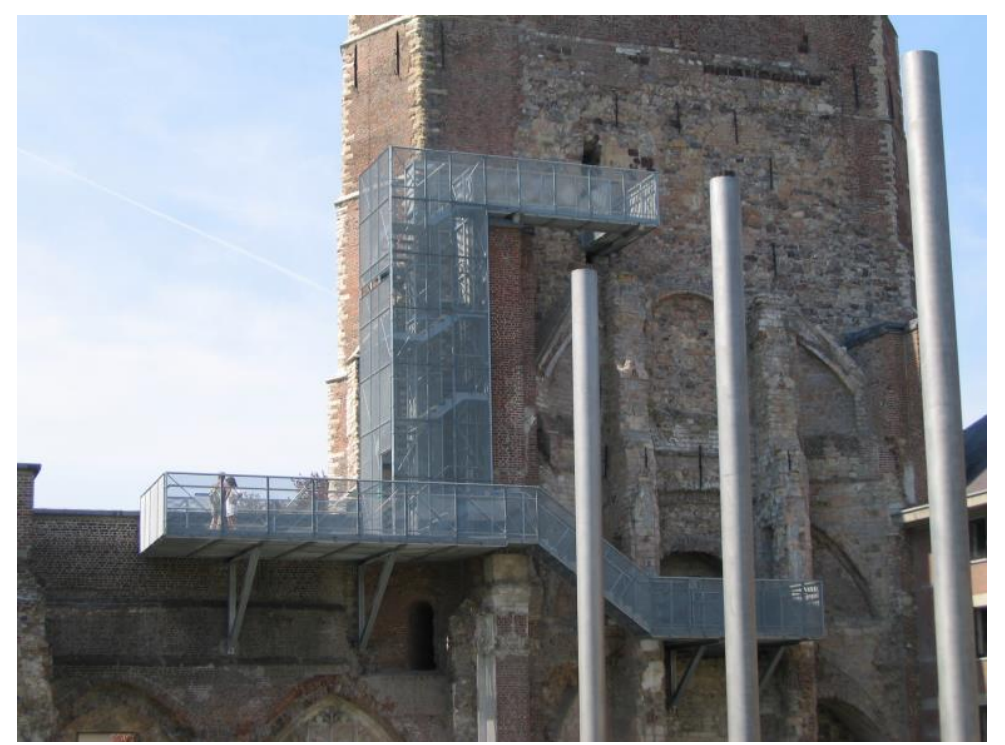

Figure 8 Observation platform at level of Baroque gate

From this platform the link between abbey and town can be discovered, as well as the urban elements connected with it. The top part of the gate wall serves as parapet, so that direct contact and touching of the walls is possible.

A veiled but still transparent staircase leads higher to the top of the old Ottonic church tower. At the level of the belfry windows of this Ottonic tower the visitor enters again the tower through a small opening. Via the old spiral stair in the north staircase tower 
the visitor climbs to an internal platform at the level of the actual belfry windows. Through these windows the contact with the site as a whole is restored.

From this internal platform a steel staircase leads to the panoramic platform on top of the tower. This platform is slightly separated from the mass of the tower shaft, Figure 9.

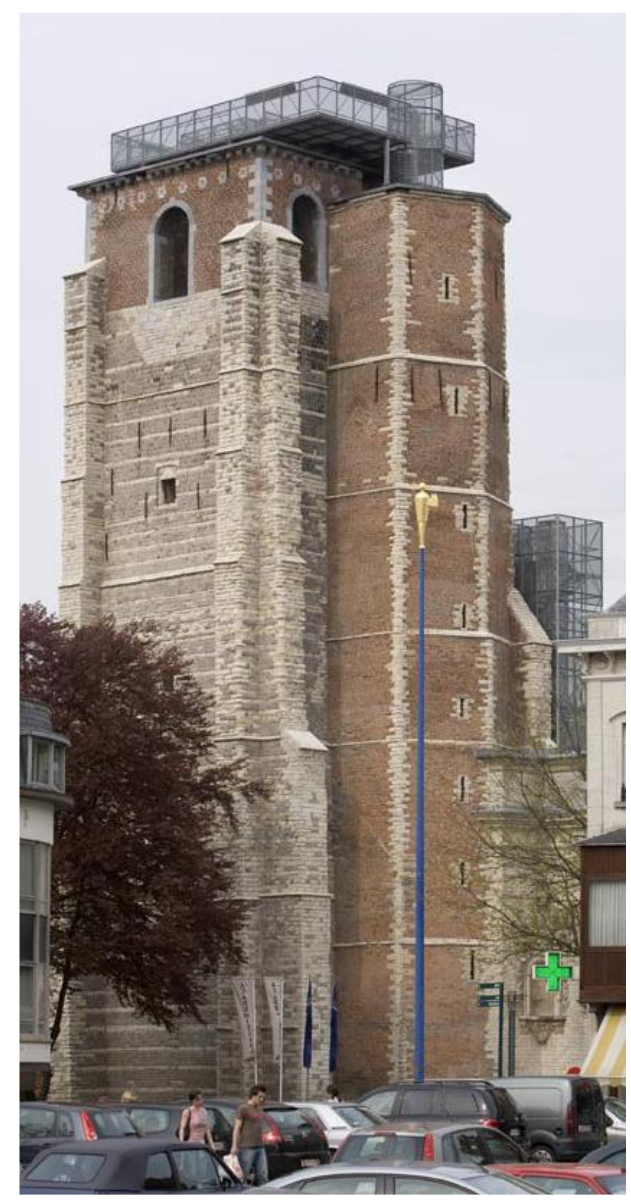

Figure 9: Panoramic platform at the top of the tower and descending spiral stair

The top platform allows a walk-round, and symbolises the panoramic view. The opening in the middle connects the inner with the outer space of the tower. The descending steel spiral stair continues in the south spiral staircase tower, and leads the visitor back to the church field.

\section{Structural consolidation of the tower}

\subsection{Degrading effects of fire on tower masonry}

\subsubsection{West wall separated from tower body}

During the fire, the tower shaft acted as a chimney, by which the walls strongly heated up. The west wall of the tower, which had been renewed after the partial collapse in 1263 , is built with natural stone blocks. The staircase towers north and south of the 
shaft are built with bricks, Fig. 9. Due to the difference in temperature expansion between natural stone masonry $\left(\alpha \approx 10-14.10^{-6} / \mathrm{K}\right)$ and brick masonry $\left(\alpha \approx 5-6.10^{-}\right.$ $6 / \mathrm{K})$, large cracks appeared in the connection zones between shaft and staircase towers, Fig. 10. These cracks penetrated the whole wall thickness, over more than half of the tower height, Fig. 11.

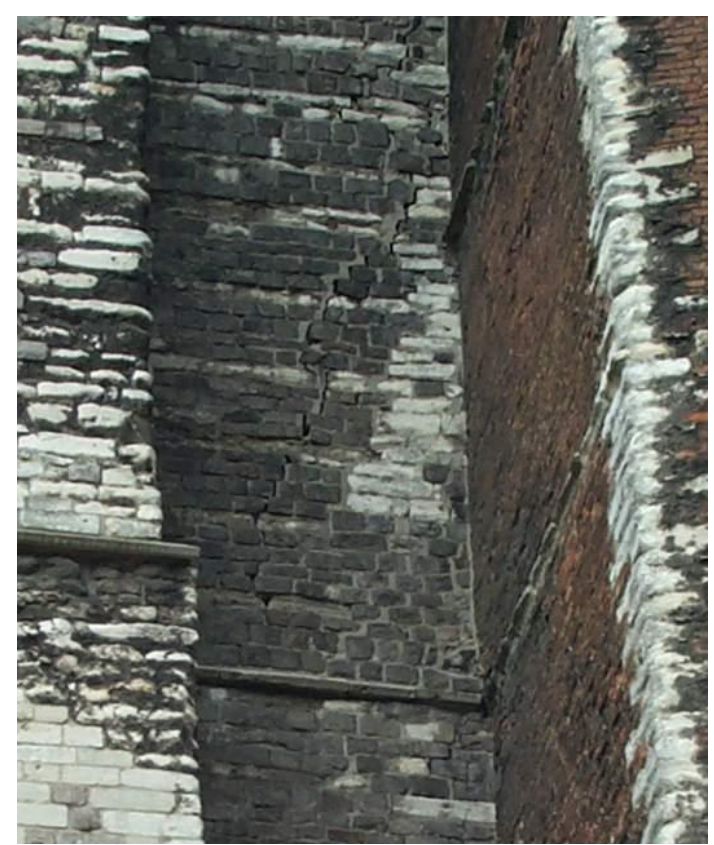

Figure 10 Inclined cracks at connection between natural stone and brick

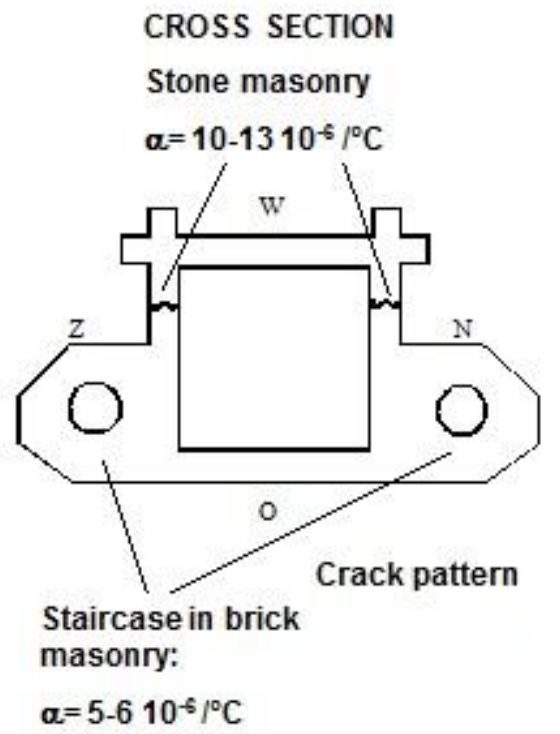

Figure 11 West wall detached from tower shaft

\subsubsection{Splitting and flaking of natural stone interior parament}

The internal parament is partly built with a quartzite sand-limestone (quartzite of Tienen). The quartz mineral expands steadily until a temperature of $573^{\circ} \mathrm{C}$. At that temperature it undergoes a sudden expansion of $0.85 \%$ caused by a transformation of 
the crystal structure [5]. As the heat of the fire inside the tower shaft easily overpassed $600^{\circ} \mathrm{C}$, the blocks strongly suffered from flaking, Fig. 12.

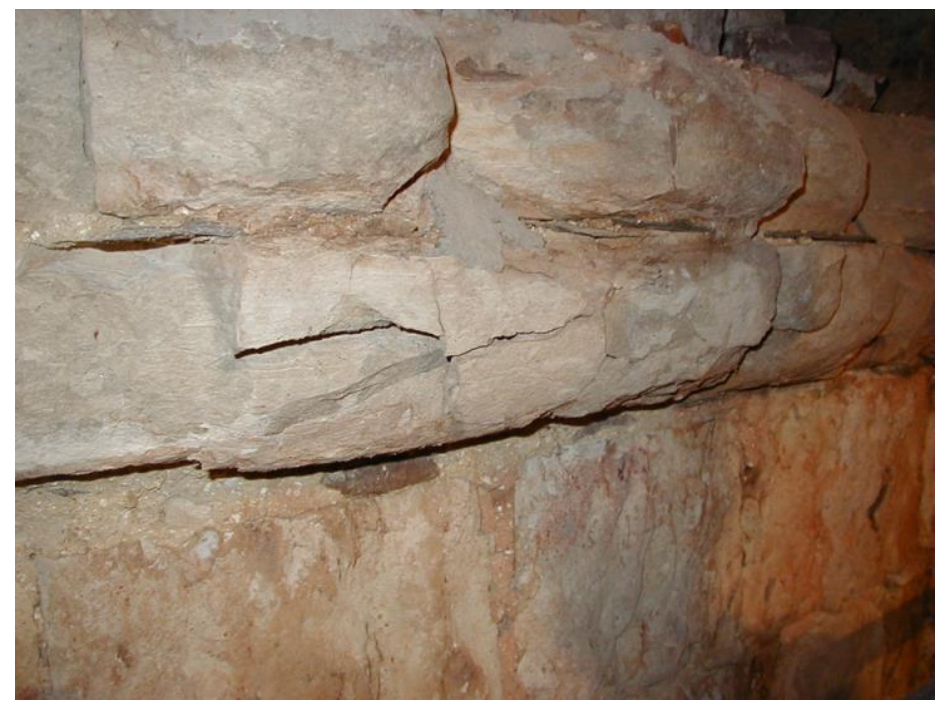

Figure 12 Splitting of natural stone blocks

\subsubsection{Separation of interior parament from core masonry}

Due to the different temperature exposure, the interior parament detached from the rubble core masonry over large surfaces. Such detached zones were searched by means of hammer sounding.

\subsection{Consolidation measures}

The structural restoration of the tower concerned the consolidation of the stone and brick masonry of the shaft by means of a ternary lime-cement-pozzolana grout injection [6]. The cement component of the grout assures the appropriate early strength development; the lime component assures the ductility of the binder, as well as the chemical and physical compatibility with the original mortars; the pozzolan replaces part of the cement, resulting in lower final strength and stiffness of the hardened grout. The grout injection also assured the required bond between the internal parament and the core masonry. The natural stone masonry part of the west façade (see Fig. 9), as well as the middle section of the tower in which the ring beams are created with grouted anchors (see Fig. 13) have been injected. A total volume of 120.000 litre of ternary grout was consumed, corresponding to a consumption of 200250 litre $/ \mathrm{m}^{2}$ of treated masonry. This high consumption is partly explained by the presence of open channels in the tower walls (part of previous rain water discharge system) and by grout losses into neighbouring walls (remains of the old church building).

Moreover, the main cracking phenomenon, with inclined cracks in the north and south wall, presented a danger for a new collapse of the west wall. Therefore, the shaft was strengthened at three levels with a ring beam, composed of cemented anchors in drilled holes, Figure 13. On top of the masonry shaft walls, a hidden reinforced concrete ring beam was placed in 1999, to serve as stabilising element for the west wall and as anchoring basis for the millennium spire. It continued to serve for the anchoring of the panoramic platform, Fig. 14. 


\section{CROSS SECTION}

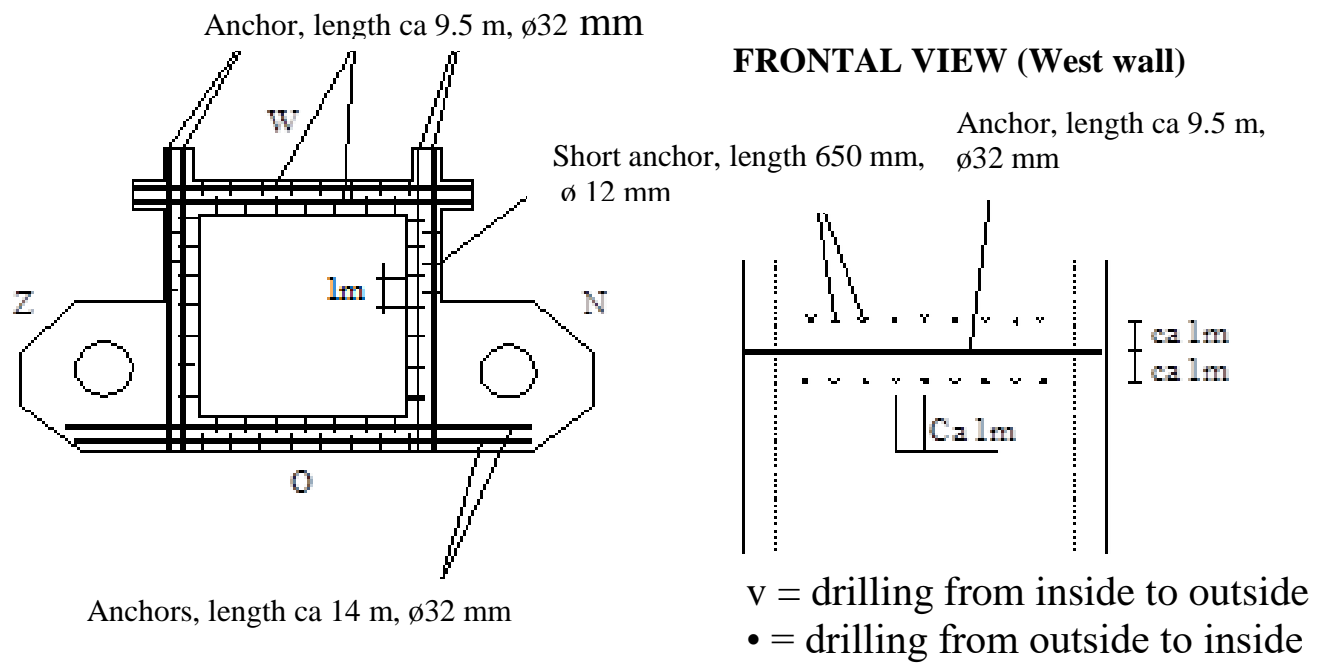

Figure 13 Position of anchors in tower shaft

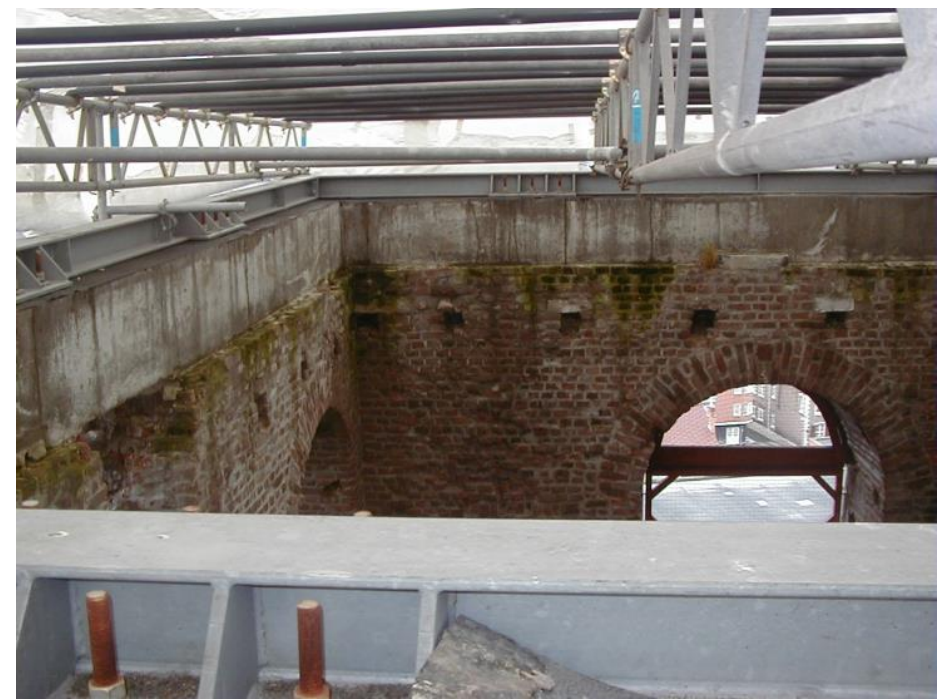

Figure 14 Anchored concrete ring beam $(0.5 \times 0.5 \mathrm{~m})$ on top of the tower walls, serving as lacing-up element and as support for panoramic platform

The main strengthening rods are complemented by small anchors with length of 650 $\mathrm{mm}$, placed in the injection holes. These small anchors must contribute to stiffen the wall area around the ring beam rods, to improve the force transfer between rods and masonry.

During the fire in 1975 the tower shaft acted as a chimney. As a consequence the internal surface stones were exposed to very high temperatures, causing splitting of these stones. In the lower part of the shaft, where visitors are able to touch the walls, the split stones are repaired by removing the loose parts piece by piece and gluing them together one by one, Fig. 12. Cracks between larger pieces were injected with an epoxy resin, Fig. 15. Heavily cracked stone parts were disassembled, and reassembled with epoxy adhesive. The obtained larger blocks were then put back and glued in the opening. 


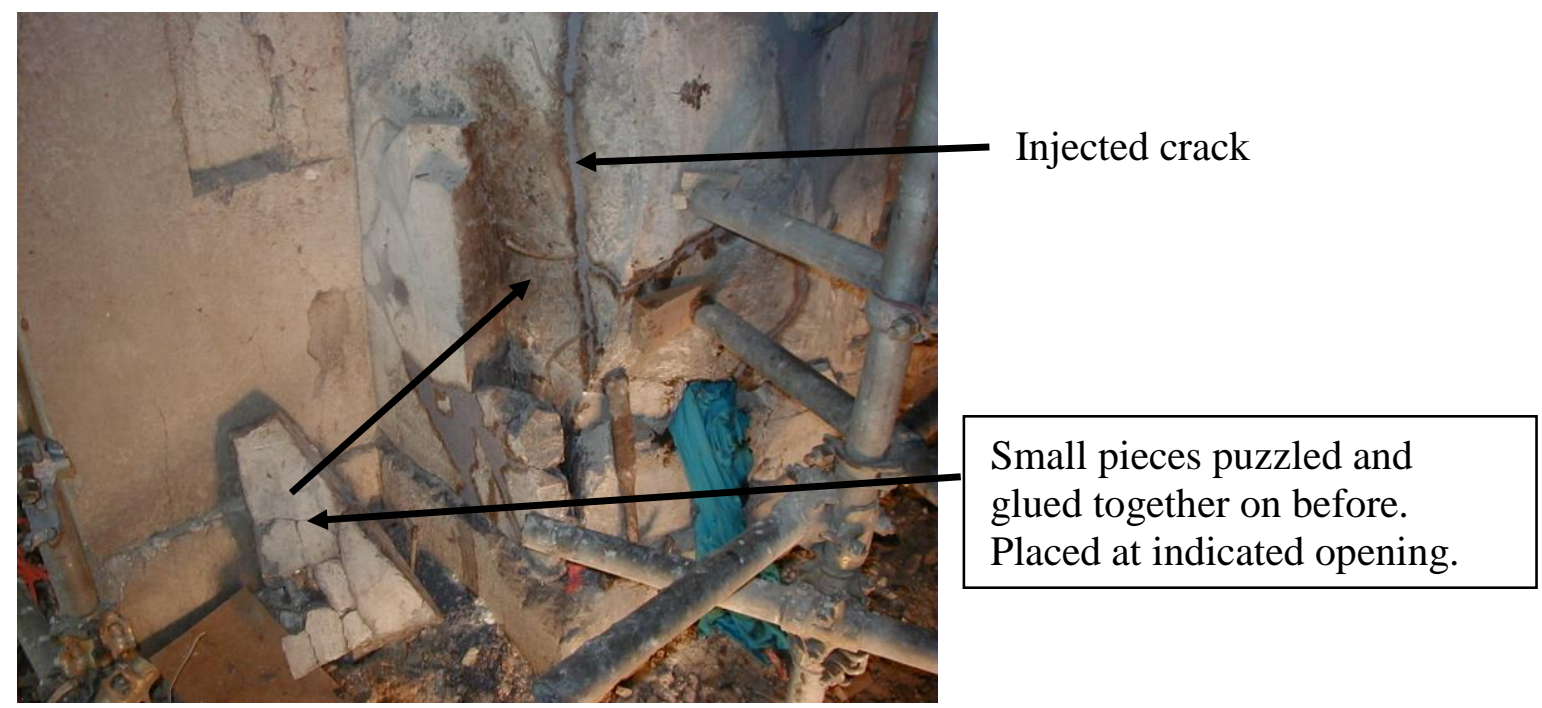

Figure 15 Disassembling and re-assembling of stone parts

As this gluing operation is very time consuming and expensive, this procedure was only applied to the visitor zones. Supplementary small anchors provide additional safety against larger fall outs of fire damaged wall parts.

\section{Conclusions}

The lifecycle of a monument can show a wide range of events, as shown by the history of the Abbey-Tower at Sint-Truiden. Restoring such a monument is not a oneman's task: it involves the input of society (the town), historians, technicians, the architect. The vision and appreciation of restoration options changes with time. It is the task of the design architect to guide the restoration process, not only in the technical sense, but even more important in the societal sense. If the architect manages to find the right compromise between the monument and the society, giving the monument the appropriate new task in the urban tissue, a successful restoration is within reach. Respectful engineering supports the revitalisation of the monument.

\section{References}

1. Van Gemert D., Brosens K., van Meer H., Restoration and opening up of the Abbey-Tower at Sint-Truiden (B), WTA-Colloquium 'Bauinstandsetzen + Bauphysik IV',Wien, 9. März 2007, WTA-Almanach 2007, pp. 381-394, ISBN 3937066-05-5

2. Ministerie van de Vlaamse Gemeenschap, Bouwen door de eeuwen heen. Inventaris van het cultuurbezit in België, vol 14, 1990

3. van Meer H., Restauratie en ontsluiting van de abdijtoren in Sint-Tuiden, internal report, 2001

4. Brosens K., Van Gemert D., Triconsult Project D00257, Restauratie Abdijtoren Sint-Truiden, 2004 (internal report) 
5 Hewlett P., Lea's chemistry of cement and concrete, Butterworth-Heinemann, 2003

6. Van Gemert D., Ignoul S., Brosens K., Toumbakari E.-E., Consolidation and strengthening of historical masonry by means of mineral grouts: grout development Restoration of Buildings and Monuments, Vol. 21, 2015, 29-45

Doi 10.1515/rbm-2015-0004 